\title{
The Electroreduction of Gadolinium and Dysprosium Ions in Equimolar NaCl-KCl Melt
}

\author{
Hasbi B. Kushkhov, Aziza S. Uzdenova, Mahmoud M. A. Saleh, \\ Abdalkader M. F. Qahtan, Lily A. Uzdenova \\ Kabardino-Balkarian State University, Nalchik, Russia \\ Email: hasbikushchov@yahoo.com,aziza_uz@yahoo.com
}

Received February 28, 2013; revised April 1, 2013; accepted May 6, 2013

Copyright (C) 2013 Hasbi B. Kushkhov et al. This is an open access article distributed under the Creative Commons Attribution License, which permits unrestricted use, distribution, and reproduction in any medium, provided the original work is properly cited.

\begin{abstract}
The mechanism of rare earth metals (Gd and Dy) chloride complexes electroreduction on the tungsten electrode in equimolar NaCl-KCl melt at $973 \mathrm{~K}$ has been studied by linear and cyclic voltammetry. Some kinetic parameters of processes were calculated. It was shown that the tungsten electrode was indifferent to gadolinium and dysprosium which were reduced on the surface. We found that the discharge mechanism of gadolinium and dysprosium chloride complexes was described by three-electron step when the steady-state conditions of polarization were limited by the mass transfer stage. The conditions of nonstationary polarization made the slowness of the charge transfer stage. The diffusion coefficient of gadolinium and dysprosium ions was calculated, the diffusion coefficient of $\mathrm{GdCl}_{6}^{3-}$ ions was $(0.9$ $\pm 0.2) \times 10^{-5} \mathrm{~cm}^{2} \cdot \mathrm{s}^{-1}$, and for $\mathrm{DyCl}_{6}^{3-}$ ions, it was $(1.60 \pm 0.2) \times 10^{-5} \mathrm{~cm}^{2} \cdot \mathrm{s}^{-1}$.
\end{abstract}

Keywords: Molten Chlorides; Gadolinium Trichloride; Dysprosium Trichloride; The Electroreduction Mechanism; Tungsten Electrode; Linear and Cyclic Voltammetry; The Diffusion Coefficient

\section{Introduction}

Understanding of the chemical and electrochemical behavior of lanthanide ions in chloride melts was an important task in view of the significant role of pyrochemical processes for the development of a new generation of nuclear reactors for transmutation of plutonium and neptunium processing, improving pyrochemical processing technologies of highly radioactive waste [1-3] and getting clean rare earth metals and various compounds based on them.

A promising way of getting rare earth metals, and in particular, gadolinium and dysprosium, as well as alloys and their compounds is the electrolysis of molten salts. For the development of an electrochemical method of their reducing, it is necessary to have reliable information on the electrochemical behavior of complexes formed by REM ions in halide melts and joint electroreduction lanthanides with the components that make up the alloy and synthesized compounds.

There is some information in literature which dedicate to the study of chemical and electrochemical behavior of gadolinium and dysprosium ions in halide and halideoxide melts. So, Spedding F. and A. Dahan [4] for the electrochemical production of rare earth metals used molten fluoride system (REM-lithium fluoride - alkali metal fluoride). As for Iosisuke H. [5], he proposed the fluoride-oxide electrolyte for production of high melting point REM (Gd, Sm, Dy, Y).

According to Plembek [6], in the eutectic $\mathrm{LiCl}-\mathrm{KCl}$ melt the metal dysprosium slowly reacts with the melt, forming a solid pale purple melt containing dysprosium in one form or another. In [7] was indicated that the gadolinium ion $\mathrm{Gd}^{3+}$ and dysprosium ion $\mathrm{Dy}^{3+}$ stable in molten $\mathrm{LiCl}-\mathrm{KCl}$, and the authors $[8,9]$ noted the possibility of formation of $\mathrm{Dy}^{3+}$ and $\mathrm{Dy}^{2+}$ ions.

The possibility of $\mathrm{Dy}^{2+}$ ions existence was also indicated in [10], where the solid metal dysprosium immersed in molten $\mathrm{LiCl}-\mathrm{KCl}-\mathrm{DyCl}_{3}$. Obtaining of $\mathrm{DyCl}_{2}$ was by the reaction $2 \mathrm{DyCl}_{3}+\mathrm{Dy} \leftrightarrow 3 \mathrm{DyCl}_{2}$. However, dichloride dysprosium disproportionate in melt into the metal dysprosium and dysprosium trichloride. Cheng et al. [11] explained the formation of the "metallic mist" over the melt by the disproportionation of $\mathrm{DyCl}_{2}$ in the melt. In another way, the authors [12] pointed that the process of $\mathrm{Dy}^{3+}$ ions electroreduction in chloride melts occured in three-electron reversible reaction. 
The electrochemical behavior of gadolinium ions and the determination of kinetic parameters of the electrode process in the low temperature chloride melt LiCl-KCl was studied by Japanese researcher Iizuka M. [13], French researchers Lantelme F. and Berghoute Y. [14], Spanish researchers Castrillejo Y. et al. [15-17].

More detailed investigation of the electrochemical behavior of dysprosium ions in eutectic LiCl-KCl melt on tungsten and aluminum electrodes was studied in [18]. The mechanism of $\mathrm{Dy}^{3+}$ ions electroreduction in LiCl$\mathrm{KCl}$ melt was proposed by using various electrochemical methods (voltammetry, chronopotentiometry, square-wave voltammetry). The authors [18] suggested that Dy ${ }^{0}$ electrodeposition on inert tungsten electrode was in two very closely spaced electrochemical steps: $\mathrm{Dy}^{3+}+1 e \rightarrow \mathrm{Dy}^{2+}$ and $\mathrm{Dy}^{2+}+2 e \rightarrow \mathrm{Dy}^{0}$. Electroreduction of $\mathrm{Dy}^{3+}$ ions on the aluminum electrode proceeded by single-stage with the formation of sustainable Dy-Al alloy.

The studying of many-electrons electrode and chemical reactions during lanthanides electroreduction and electrochemical synthesis of rare earth alloys and compounds from higher temperature equimolar $\mathrm{NaCl}-\mathrm{KCl}$ melt was held in works [19-21]. The electroreduction of these rare earth ions in particular Gd was studied on silver and platinum electrodes, which interacted with the reduced metal and formed alloys and intermetallic compounds. It led to the depolarization of the electrode process and complicated the establishment of the mechanism and the nature of the electrode process of electroreduction halide complexes REM.

The studying of rare-earth ions electroreduction [22-24] showed that tungsten is the most indifferent electrode material.

Thus, analysis of published data on the electrochemical behavior of gadolinium and dysprosium ions in chloride melts shows: firstly, there are few works and limited information on this issue, and secondly, the available information is often inconsistent and there is no consensus on the mechanism of REM ions electroreduction in chloride melts, and thirdly, most of the studies carried out on the background of a low-temperature $\mathrm{LiCl}-\mathrm{KCl}$ melt; fourthly, as for dysprosium, if there is no doubt about the corrosion of metal dysprosium in molten $\mathrm{LiCl}-\mathrm{KCl}-\mathrm{DyCl}_{3}$ with produced $\mathrm{Dy}^{2+}$ ions is no doubt, that the mechanism, according to the electroreduction of $\mathrm{Dy}^{3+}$ ions on the inert electrode in two very close cathode stage insufficiently substantiated, requires further research.

Thus, based on the studies conducted earlier by various authors, in this paper we tried to eliminate the alloy effect and identify the true mechanism of the electrode process and studied the electrochemical behavior of chloride complexes of gadolinium and dysprosium on tungsten electrode in equimolar $\mathrm{NaCl}-\mathrm{KCl}$ melt.

\section{Experimental}

\subsection{Chemicals and Apparatus}

Anhydrous gadolinium and dysprosium chloride is very hygroscopic substances. Anhydrous trichlorides prepared from hexahydrate $\mathrm{LnCl}_{3} \cdot 6 \mathrm{H}_{2} \mathrm{O}$ by the known method [25], where the dehydrating agent was the ammonium chloride. All operations with anhydrous chlorides were carried out in glovebox mBraun Labstar 50 in the argon atmosphere. Experiments were carried out in a sealed quartz cell (Figure 1) in the argon atmosphere, purified from traces of moisture and oxygen, which is necessary in order to obtain reliable results.

In three-electrode cell, the working electrode was the tungsten $(\varnothing=1.0 \mathrm{~mm})$ needle electrode. As the reference electrode we used quasireversible glassy carbon rod electrode. The using of glassy carbon quasi-electrode help as to avoid the using of oxygen-diaphragms. Oxide ceramics are not compatible with the halide melts containing rare earth ions.

Glassy carbon quasistationary reference electrode, apparently, is a compromise electrode, and is determined

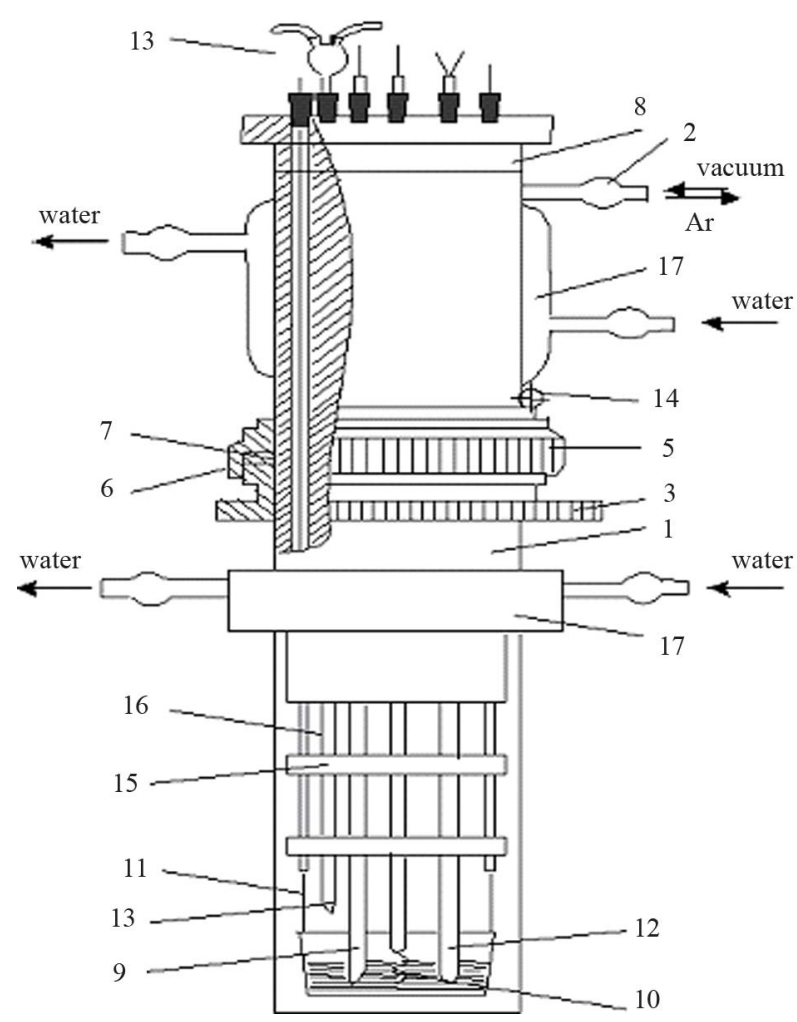

Figure 1. Scheme of high temperature electrochemical quartz cell. 1-quartz body, 2-union for degassing of the cell, 3-ring threaded, 4-PTFE bushing, 5-steel clamping nut, 6-vacuum rubber ring, 7-ring PTFE, 8-tube from the vacuum rubber, 9-indicate electrode, 10-reference electrode, 11-current leads wire to the anode, 12-thermocouple, 13-boot device, 14-circlip, 15-serpentine washers, 16-porcelain tube, 17-cooling casing. 
by the redox potentials are established with the participation of the various components of the molten medium. Therefore, its value depends on the melt composition and temperature. Glassy carbon quasistationary reference electrode was used in our studies [22], and previously by the authors [26] in chloride and chloride-fluoride melts. The anode was the glassy carbon crucible, which was the container for melt at the same time.

Electroreduction of gadolinium and dysprosium ions was investigated by cyclic voltammetry at scan rate from 0.01 to $1.0 \mathrm{~V} \cdot \mathrm{s}^{-1}$. The current-voltage dependence was obtained by the electrochemical complex Autolab PGST 30 (Ecochemic, Holland), which was paired with the computer. Equimolar mixture of $\mathrm{NaCl}-\mathrm{KCl}$ was used by solvent. It was prepared from previously recrystallized and dried under vacuum at 423 - $472 \mathrm{~K}$ chloride followed by melting in the argon atmosphere. The electrodes which ware used in the experiments, mechanically cleaned by the fine sandpaper, then were polished [27].

\section{Results and Discussion}

The cyclic voltammograms of gadolinium and dysprosium ions electroreduction process on a tungsten electrode in chloride melt shows in Figures 2 and $\mathbf{3}$ respectively.

The absence of any waves on the background curve (Figure 2, curves 1) and low residual current at relatively high negative potentials lead to the conclusion about purity of the background electrolyte. At the concentration of rare-earth metals trichlorides in the melt about $1.0 \times$ $10^{-4} \mathrm{~mol} \cdot \mathrm{cm}^{-3}$ the electroreduction wave appears on the voltammograms at potentials $(-2.30--2.40) \mathrm{V}$ for $\mathrm{Gd}$ ions and $(-2.25--2.35) \mathrm{V}$ for Dy ions relative quasireversible glassy carbon electrode. As seen from the

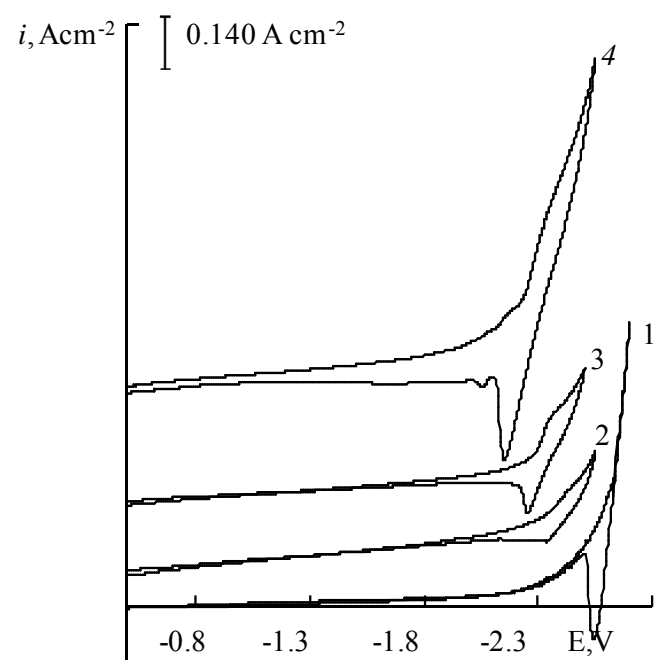

Figure 2. Cyclic voltammograms of $\mathrm{NaCl}-\mathrm{KCl}-\mathrm{GdCl}_{3}$ melt at $973 \mathrm{~K} . \mathrm{C}\left(\mathrm{GdCl}_{3}\right) \times 10^{4}, \mathrm{~mol} \cdot \mathrm{cm}^{-3}: 1$ - 0,2 - 1.8, 3 - 3.0, 4 - 4.5. Working electrode: $\mathrm{W}$, scan rate $=0.05 \mathrm{~V} \cdot \mathrm{s}^{-1}$. cyclic voltammograms, the increasing of the depolarizer concentration leads to the increase of height of electroreduction wave (Figures $\mathbf{2}$ and $\mathbf{3}$ ).

We studied the influence of scan rate on the process of Gd and Dy ions electroreduction. The voltammograms (Figures 4 and 5) were taken as in stationary and nonstationary polarization $\left(0.01 \mathrm{~V} \cdot \mathrm{s}^{-1} \leq \mathrm{V} \leq 2.0 \mathrm{~V} \cdot \mathrm{s}^{-1}\right)$. The change of scan rate from stationary to nonstationary doesn't give the appearance of diffusion peak on current-voltage curves (Figures 4 and 5).

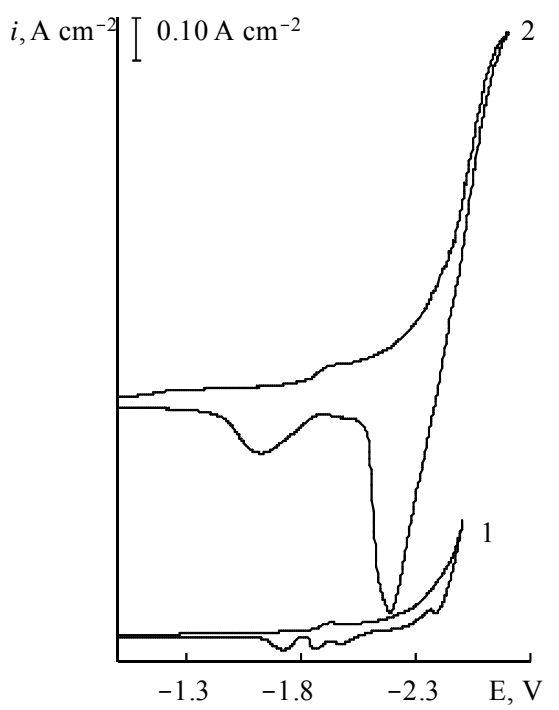

Figure 3. Cyclic voltammogramms of $\mathrm{NaCl}-\mathrm{KCl}-\mathrm{DyCl}_{3}$ melt at $973 \mathrm{~K} . \mathrm{C}\left(\mathrm{DyCl}_{3}\right) \times 10^{4}, \mathrm{~mol} \cdot \mathrm{cm}^{-3}: 1-2.3,2-2.9$. Working electrode: $\mathrm{W}$, scan rate $=0.1 \mathrm{~V} \cdot \mathrm{s}^{-1}$.

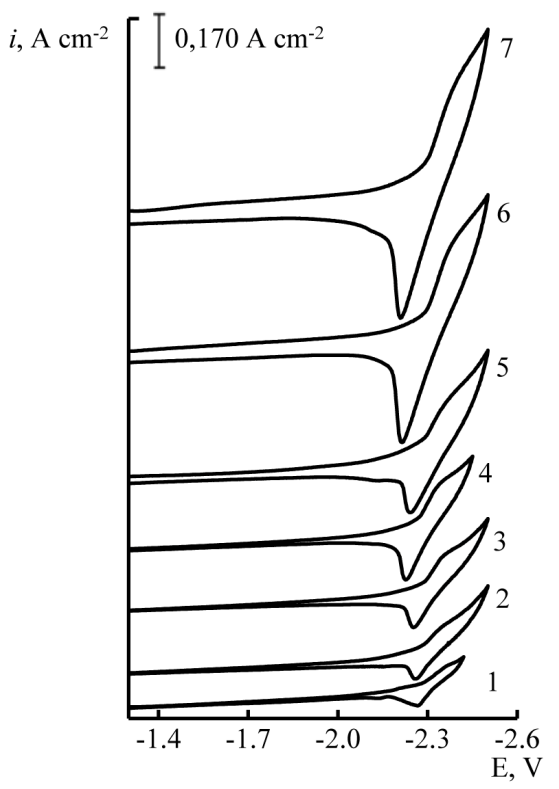

Figure 4. Cyclic voltammograms of $\mathrm{NaCl}-\mathrm{KCl}-\mathrm{GdCl}_{3}$ melt at different scan rate, $\mathrm{V} \cdot \mathrm{s}^{-1}: 1-0.01,2-0.02,3-0.05,4-0.1,5$ - 0.2, 6 - 0.5, 7 - 1.0. $\mathrm{C}\left(\mathrm{GdCl}_{3}\right)=3.0 \times 10^{-4} \mathrm{~mol} \cdot \mathrm{cm}^{-3}$, working electrode: $\mathrm{W}, \mathrm{T}=973 \mathrm{~K}$. 


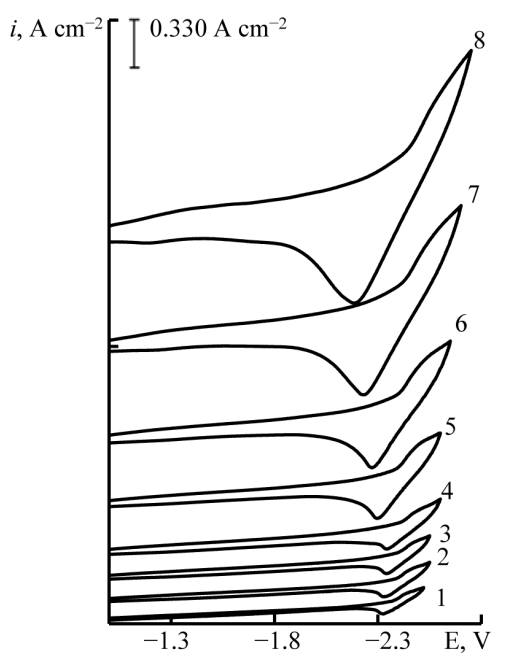

Figure 5. Cyclic voltammograms of $\mathrm{NaCl}-\mathrm{KCl}-\mathrm{DyCl}_{3}$ melt at different scan rate, $\mathrm{V} \cdot \mathrm{s}^{-1}: 1-0.01,2-0.02,3-0.03,4$ $0.05,5-0.1,6-0.2,7-0.5,8-1.0 . \mathrm{C}\left(\mathrm{DyCl}_{3}\right)=5.0 \times 10^{-4}$ $\mathrm{mol} \cdot \mathrm{cm}^{-3}$, working electrode: $\mathrm{W}, \mathrm{T}=973 \mathrm{~K}$.

Cyclic voltammograms at different return potentials presented in Figures $\mathbf{6}$ and $\mathbf{7}$ for the process of Gd and Dy ions electroreduction, respectively. They allow to correlate the wave of cathodic reduction and wave of anodic oxidation. If we would limit the value of the polarization potential to $-2.5 \mathrm{~V}$ for $\mathrm{Gd}$ ions and $-2.55 \mathrm{~V}$ for Dy ions, than the anode loop there was only one wave of cathodic dissolution cycle-lanthanide metal.

This picture can be explained by the proximity of the recovery potential of complex chloride ions (Gd and Dy) with recovery potentials of alkali metals. It should also be noted that the height of the anodic wave of the current-voltage curves increases with increasing concentration of the depolarizer in the melt (Figures $\mathbf{2}$ and $\mathbf{3}$ ).

To establish the nature and mechanism of the electrode process of REM ions electroreduction in chloride melts we calculated the current density, the potential peak and half-peak, half width of the peak at different concentrations of $\mathrm{GdCl}_{3}$ and $\mathrm{DyCl}_{3}$ and scan rates by well-known diagnostic criteria. Limiting current electroreduction as gadolinium ions and ions of dysprosium in direct proportion increases with increasing concentration of $\mathrm{LnCl}_{3}$ (Ln-Gd, Dy) in melt (Figures 8 and 9).

Our results indicate the diffusion control of process of gadolinium and dysprosium ions electroreduction in molten $\mathrm{NaCl}-\mathrm{KCl}$ at stationary state polarization. At this fact also indicates the value of the ratio

$i_{d} / n F C=(1.0-3.0) \cdot 10^{-3} \mathrm{~cm} \cdot \mathrm{s}^{-1}$ for the both ions, which characterizes the method of delivery of electroactive species to the electrode surface, the value of which is comparable with the diffusion constant $\chi=D / \delta$.

The diffusion control of the electrode process is confirmed by the form of $i_{\mathrm{p}} / \mathrm{V}^{1 / 2}-\mathrm{V}^{1 / 2}$ dependence. In the rates of the polarization up $0.01 \mathrm{~V} \cdot \mathrm{s}^{-1}$ to $0.1 \mathrm{~V} \cdot \mathrm{s}^{-1}$ observed constancy of the $i_{p} / \mathrm{V}^{1 / 2}-\mathrm{V}^{1 / 2}$ ratio (Tables 1 and 2, Figures 10 and 11).

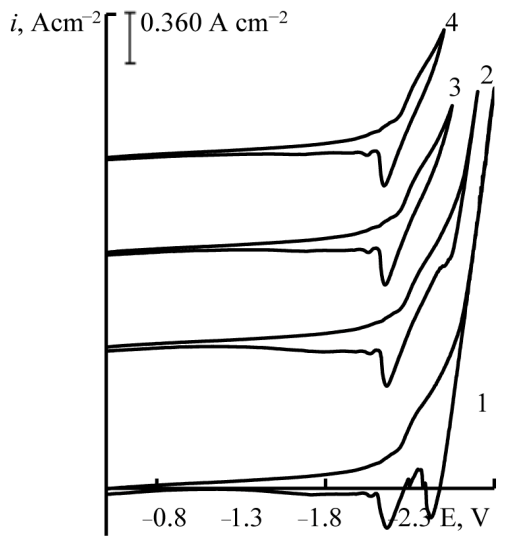

Figure 6. Cyclic voltammograms of $\mathrm{NaCl}-\mathrm{KCl}-\mathrm{GdCl}_{3}$ melt at different return potentials, $V: 1$ - $(-2,80) ; 2$ - (-2.70); 3 $(-2.50) ; 4-(-2.45)$, scan rate $=0.05 \mathrm{~V} \cdot \mathrm{s}^{-1} . \mathrm{C}\left(\mathrm{GdCl}_{3}\right)=4.5 \times$ $10^{-4} \mathrm{~mol} \cdot \mathrm{cm}^{-3}$, working electrode: $\mathrm{W}, \mathrm{T}=973 \mathrm{~K}$.

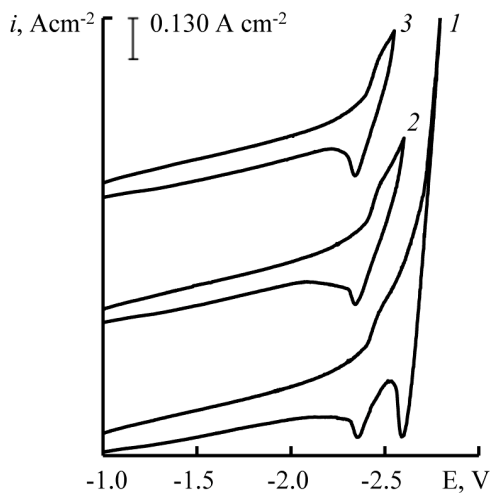

Figure 7. Cyclic voltammograms of $\mathrm{NaCl}-\mathrm{KCl}-\mathrm{DyCl}_{3}$ melt at different return potentials, $V: 1-(-2.80) ; 2$ - (-2.60); 3 $(-2.55)$, scan rate $=0.03 \mathrm{~V} \cdot \mathrm{s}^{-1} . \mathrm{C}\left(\mathrm{DyCl}_{3}\right)=5.0 \times 10^{-4}$ mol $\cdot \mathrm{cm}^{-3}$, working electrode: $\mathrm{W}, \mathrm{T}=973 \mathrm{~K}$.

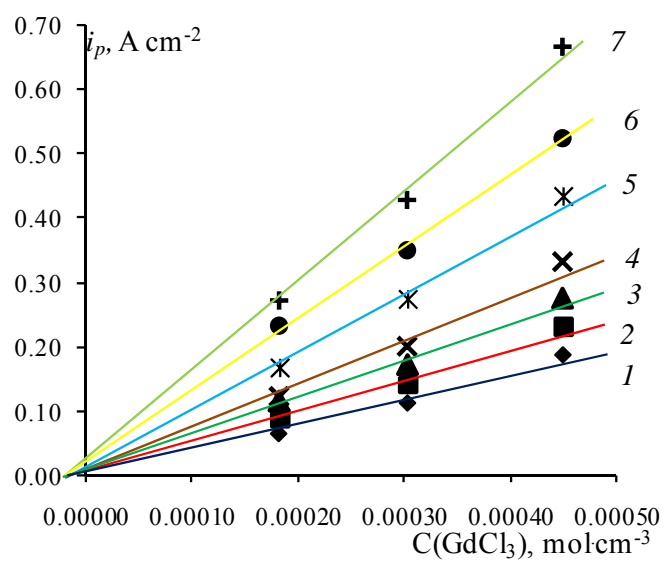

Figure 8. Electroreduction current- $\mathrm{GdCl}_{3}$ concentration dependence in $\mathrm{NaCl}-\mathrm{KCl}-\mathrm{GdCl}_{3}$ melt. Scan rate, $\mathrm{V} \cdot \mathrm{s}^{-1}: 1$ $0.02,2$ - 0.05, 3 - 0.07, 4 - 0.1, 5 - 0.2, 60 - 0.5, 7 - 1.0, working electrode: $W, T=973 \mathrm{~K}$. 


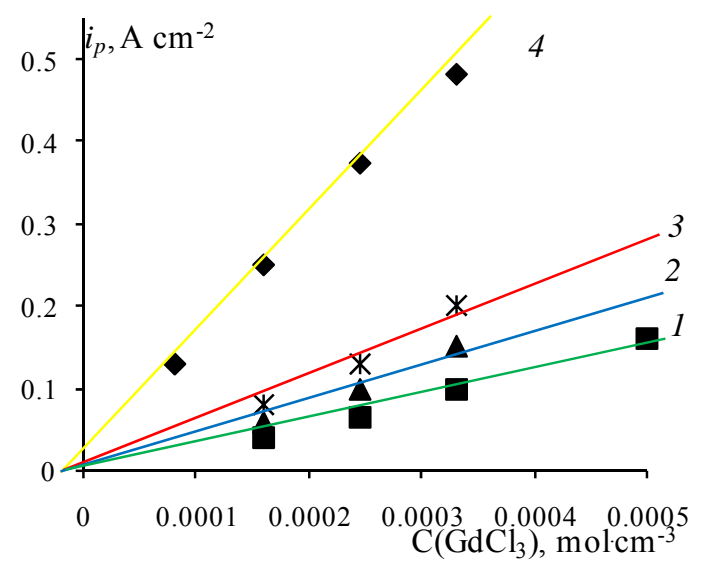

Figure 9. Electroreduction current- $-\mathrm{DyCl}_{3}$ concentration dependence in $\mathrm{NaCl}-\mathrm{KCl}-\mathrm{DyCl} \mathrm{Cl}_{3}$ melt. Scan rate, $\mathrm{V} \cdot \mathrm{s}^{-1}: 1$ $0.02,2$ - 0.05, 3 - 0.1, 4 - 0.2, working electrode: $W, T=973 \mathrm{~K}$.
For determine of the electrons number, which transferred in the electrode process, the analysis of stationary state current-voltage curves was made by the Heyrovsky-Ilkovich equation [28].

The slope of the $E-\lg \left[i / i_{d}-i\right]$ dependence is given the value of electron number $n=3$ (Figures 12 and 13).

The current ratio of the anodic and cathodic peaks by electroreduction on the tungsten electrode at the scan rate upto $0.1 \mathrm{~V} \cdot \mathrm{s}^{-1}$ near 1.0 (Figures 4 and $\mathbf{5}$ ), which is typical for a reversible electrode process.

The values of the number of electrons transferred in the electrode process, which was calculated by the wellknown diagnostic criteria for the half-width of the peak was close to three at the scan rate up to $0.1 \mathrm{~V} \cdot \mathrm{s}^{-1}$. The increasing of the scan rate higher than $0.1 \mathrm{~V} \cdot \mathrm{s}^{-1}$ leads to a broadening of wave. Analysis of the half-widths of the

Table 1. Some electrochemical parameters of $\mathrm{GdCl}_{3}$ electroreduction on the tungsten electrode in $\mathrm{molten} \mathrm{NaCl}-\mathrm{KCl}(1: 1)$, $\mathrm{T}=$ $973 \mathrm{~K}$.

\begin{tabular}{|c|c|c|c|c|c|c|}
\hline $\mathrm{V}, \mathrm{V} \cdot \mathrm{s}^{-1}$ & $i_{p}, A \cdot \mathrm{cm}^{-2}$ & $\mathrm{i}_{\mathrm{p}} / \mathrm{V}^{1 / 2}$ & $\varphi_{\mathrm{p}}^{\mathrm{k}}, \mathrm{V}$ & $\varphi_{\mathrm{p} / 2}{ }^{\mathrm{k}}, \mathrm{V}$ & $\Delta \varphi^{\mathrm{k}}, \mathrm{V}$ & $\mathrm{n}\left(\alpha \mathrm{m}_{\alpha}\right)$ \\
\hline \multicolumn{7}{|c|}{$\mathrm{C}\left(\mathrm{GdCl}_{3}\right)=1.8 \times 10^{-4} \mathrm{~mol} \cdot \mathrm{cm}^{-3}$} \\
\hline 0.5 & 0.250 & 0.35 & -2.495 & -2.415 & 0.080 & 1.95 \\
\hline 0.2 & 0.150 & 0.3400 & -2.436 & -2.365 & 0.071 & 2.19 \\
\hline 0.07 & 0.115 & 0.4300 & -2.374 & -2.315 & 0.059 & 3.15 \\
\hline 0.05 & 0.090 & 0.4000 & -2.369 & -2.308 & 0.061 & 3.05 \\
\hline \multicolumn{7}{|c|}{$\mathrm{C}\left(\mathrm{GdCl}_{3}\right)=3.0 \times 10^{-4} \mathrm{~mol} \cdot \mathrm{cm}^{-3}$} \\
\hline 1.0 & 0.465 & 0.4650 & -2.439 & -2.349 & 0.090 & 1.73 \\
\hline 0.5 & 0.350 & 0.4950 & -2.412 & -2.333 & 0.079 & 1.97 \\
\hline 0.2 & 0.253 & 0.5667 & -2.382 & -2.316 & 0.066 & 2.36 \\
\hline 0.1 & 0.170 & 0.5380 & -2.373 & -2.310 & 0.063 & 2.95 \\
\hline 0.07 & 0.172 & 0.6490 & -2.373 & -2.314 & 0.059 & 3.15 \\
\hline 0.05 & 0.142 & 0.6324 & -2.373 & -2.312 & 0.061 & 3.05 \\
\hline 0.02 & 0.088 & 0.6245 & -2.362 & -2.303 & 0.059 & 3.15 \\
\hline 0.01 & 0.068 & 0.6833 & -2.362 & -2.304 & 0.058 & 3.20 \\
\hline \multicolumn{7}{|c|}{$\mathrm{C}\left(\mathrm{GdCl}_{3}\right)=4.5 \times 10^{-4} \mathrm{~mol} \cdot \mathrm{cm}^{-3}$} \\
\hline 2.0 & 0.800 & 0.5660 & -2.421 & -2.312 & 0.109 & 1.43 \\
\hline 1.0 & 0.643 & 0.6433 & -2.409 & -2.313 & 0.106 & 1.47 \\
\hline 0.5 & 0.523 & 0.7402 & -2.381 & -2.295 & 0.086 & 1.81 \\
\hline 0.2 & 0.437 & 0.9769 & -2.370 & -2.295 & 0.075 & 2.08 \\
\hline 0.1 & 0.367 & 1.1603 & -2.368 & -2.299 & 0.069 & 2.70 \\
\hline 0.07 & 0.291 & 1.1002 & -2.367 & -2.308 & 0.059 & 3.15 \\
\hline 0.05 & 0.263 & 1.1756 & -2.326 & -2.268 & 0.058 & 3.20 \\
\hline 0.02 & 0.165 & 1.1669 & -2.307 & -2.248 & 0.059 & 3.15 \\
\hline 0.01 & 0.119 & 1.1920 & -2.292 & -2.232 & 0.060 & 3.10 \\
\hline
\end{tabular}


Table 2. Some electrochemical parameters of $\mathrm{DyCl}_{3}$ electroreduction on the tungsten electrode in molten $\mathrm{NaCl}-\mathrm{KCl}(1: 1)$, $\mathrm{T}=$ $973 \mathrm{~K}$.

\begin{tabular}{|c|c|c|c|c|c|c|}
\hline $\mathrm{V}, \mathrm{Vs}^{-1}$ & $\mathrm{i}_{\mathrm{p}}, \mathrm{A} \mathrm{cm}^{-2}$ & $\mathrm{i}_{\mathrm{p}} / \mathrm{V}^{1 / 2}$ & $\varphi_{\mathrm{p}}^{\mathrm{k}}, \mathrm{V}$ & $\varphi_{\mathrm{p} / 2}{ }^{\mathrm{k}}, \mathrm{V}$ & $\Delta \phi^{k}, \mathrm{~V}$ & $\mathrm{n}\left(\alpha \mathrm{n}_{\alpha}\right)$ \\
\hline \multicolumn{7}{|c|}{$\mathrm{C}\left(\mathrm{DyCl}_{3}\right)=5.0 \times 10^{-4} \mathrm{~mol} \cdot \mathrm{cm}^{-3}$} \\
\hline 1.0 & 1.455 & 1.455 & 2.653 & 2.519 & 0.140 & 1.11 \\
\hline 0.5 & 1.160 & 1.641 & 2.599 & 2.490 & 0.109 & 1.43 \\
\hline 0.2 & 0.773 & 1.730 & 2.550 & 2.453 & 0.097 & 1.60 \\
\hline 0.1 & 0.573 & 1.814 & 2.506 & 2.436 & 0.070 & 2.66 \\
\hline 0.05 & 0.405 & 1.808 & 2.482 & 2.419 & 0.063 & 2.95 \\
\hline 0.03 & 0.266 & 1.538 & 2.495 & 2.431 & 0.064 & 2.91 \\
\hline
\end{tabular}

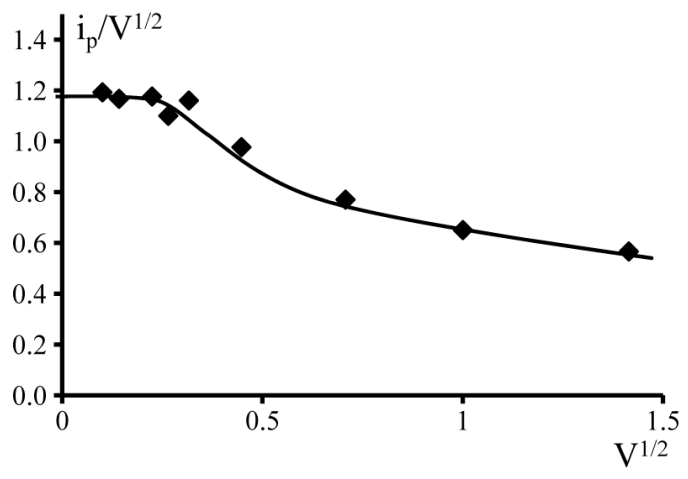

Figure 10. $\mathrm{i}_{\mathrm{p}} / \mathrm{V}^{1 / 2}-\mathrm{V}^{1 / 2}$ dependence for $\mathrm{NaCl}-\mathrm{KCl}-\mathrm{GdCl}_{3}(4.5 \times$ $10^{-4} \mathrm{~mol} \cdot \mathrm{cm}^{-3}$ ) melt. Working electrode: $\mathrm{W}, \mathrm{T}=973 \mathrm{~K}$.

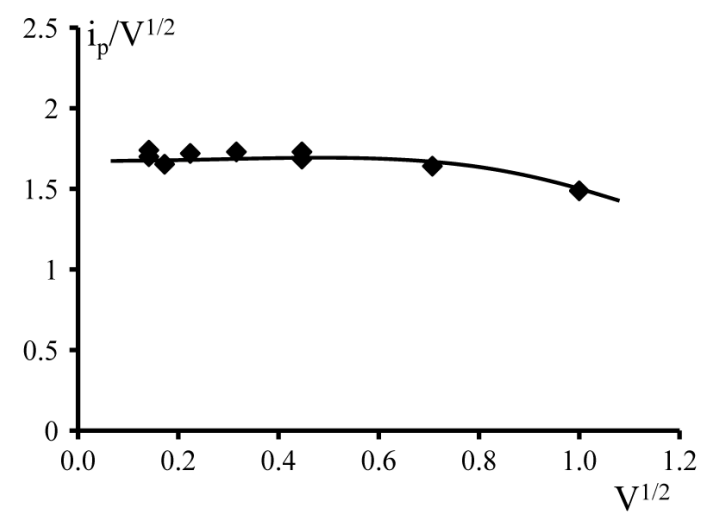

Figure 11. $i_{p} / V^{1 / 2}-V^{1 / 2}$ dependence for $\mathrm{NaCl}-\mathrm{KCl}-\mathrm{DyCl}_{3}(5.0$ $\times 10^{-4} \mathrm{~mol} \cdot \mathrm{cm}^{-3}$ ) melt. Working electrode: $W, T=973 \mathrm{~K}$.

peaks for these scan rates by the diagnostic criteria of Matsuda, Ayabe and Delahey [29-31] gives the value $\alpha \mathrm{n}_{\alpha}=1.1-1.8$.

Thus, the electrode process of gadolinium and dysprosium chloride complexes, which was recovered on a tungsten electrode in chloride melts under stationary and unstationary conditions of polarization to the scan rate $0.1 \mathrm{~V} \cdot \mathrm{s}^{-1}$ is limited by the diffusion stage of delivery, and at non-stationary conditions of polarization limited by the rate of charge transfer.

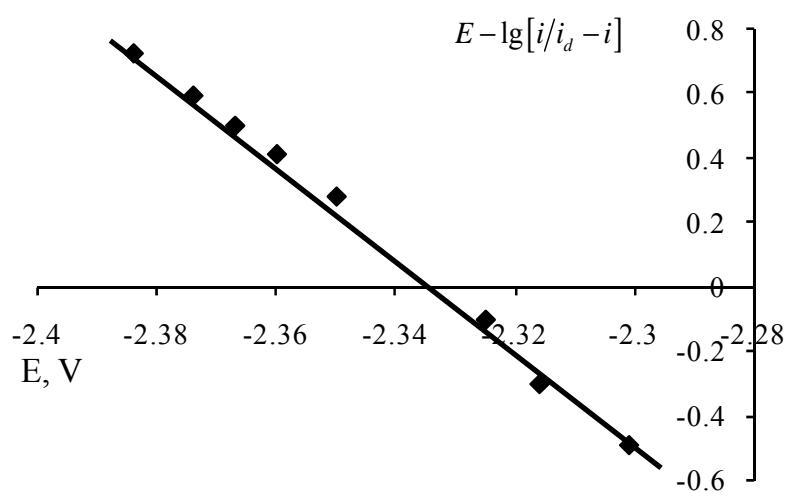

Figure 12. $E-\lg \left[i / i_{d}-i\right]$ dependence for $\mathrm{NaCl}-\mathrm{KCl}-\mathrm{GdCl}_{3}$ $\left(3.0 \times 10^{-4} \mathrm{~mol} \cdot \mathrm{cm}^{-3}\right)$ melt. Scan rate $=0.01 \mathrm{~V} \cdot \mathrm{s}^{-1}$. Working electrode: $\mathrm{W}, \mathrm{T}=973 \mathrm{~K}$.

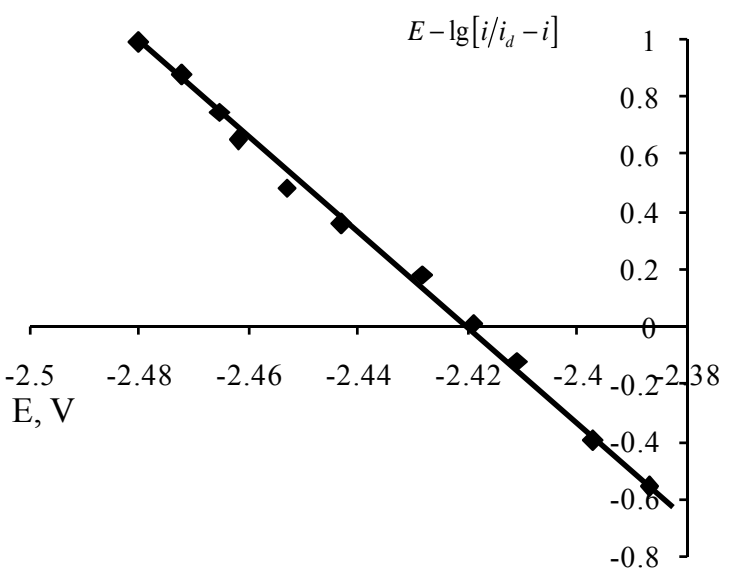

Figure 13. $E-\lg \left[i / i_{d}-i\right]$ dependence for $\mathrm{NaCl}-\mathrm{KCl}-\mathrm{DyCl}_{3}$ $\left(5.0 \times 10^{-4} \mathrm{~mol} \cdot \mathrm{cm}^{-3}\right)$ melt. Scan rate $=0.01 \mathrm{~V} \cdot \mathrm{s}^{-1}$. Working electrode: $\mathbf{W}, \mathbf{T}=973 \mathrm{~K}$.

With using data on the structure of rare earth chloride complexes, and in particular, gadolinium and dysprosium, according to which they exist in pure chloride melts in the form of complex $\mathrm{LnCl}_{6}^{3-}$, the electroreduction process can be represented by the following reaction: 


$$
\mathrm{LnCl}_{6}{ }^{3-}+3 e \leftrightarrow \mathrm{Ln}+6 \mathrm{Cl}^{-}
$$

when Ln-Gd, Dy.

We calculated the diffusion coefficient of the $\mathrm{LnCl}_{6}^{3-}$ complex ions with using the following equation:

$$
i_{p}=0.446 \frac{F^{3 / 2}}{R^{1 / 2} T^{1 / 2}} n^{3 / 2} C_{O X} D_{O x}^{1 / 2} V^{1 / 2}
$$

Calculation of ion diffusion coefficient of $\mathrm{LnCl}_{6}^{3-}$ ion performed for the scan rate when the value of $i_{\mathrm{p}} / \mathrm{V}^{1 / 2}$ constantly and the electrode process is reversible (Figures 9 and 10). The diffusion coefficient of $\mathrm{GdCl}_{6}^{3-}$ ions is $(0.9 \pm 0.2) \times 10^{-5} \mathrm{~cm}^{2} \cdot \mathrm{s}^{-1}$, and for $\mathrm{DyCl}_{6}^{3+}$ ions this value is $(1.60 \pm 0.2) \cdot 10^{-5} \mathrm{~cm}^{2} \cdot \mathrm{s}^{-1}$.

These values were in good agreement with early published data [15-17].

\section{Conclusion}

The result of our investigations shows that the electroreduction of gadolinium and dysprosium chloride complexes ions on tungsten electrode in equimolar $\mathrm{KCl}-\mathrm{NaCl}$ melt occurs in three-electron step at stationary and nonstationary polarization up to $0.1 \mathrm{~V} \cdot \mathrm{s}^{-1}$ and it is limited by the diffusion stage, and the higher scan rates lead to the slowness stage charge transfer.

\section{Acknowledgements}

The work was done using equipment of Access Center "X-ray diagnosis of materials" with the financial support of the Ministry of Education and Science of Russian Federation, the state contract No. 16552.11.7074.

\section{REFERENCES}

[1] T. Nishimura, T. Koyama, M. Iizuka and T. Tanaka, "Development of an Environmentally Benign Reprocessing Technology-Pyrometallurgical Reprocessing Technology," Progress in Nuclear Energy, Vol. 32, No. 3/4, 1998, pp. 381-385. doi:10.1016/S0149-1970(97)00032-2

[2] J. J. Laidler, J. E. Battles, W. E. Miller, J. P. Ackerman and E. L. Carls, "Development of Pyroprocessing Technology," Progress in Nuclear Energy, Vol. 31, No. 1-2, 1997, pp. 131-140. doi:10.1016/0149-1970(96)00007-8

[3] K. Kinoshita, T. Inoue, S. P. Fusselman, D. L. Grimmett, J. J. Roy, R. L. Gay, C. L. Krueger, C. R. Nabelek and T. S. Storvick, "Separation of Uranium and Transuranic Elements from Rare Earth Elements by Means of Multistage Extraction in $\mathrm{LiCl}-\mathrm{KCl} / \mathrm{Bi}$ System," Journal of Nuclear Science and Technology, Vol. 36, No. 2, 1999, pp. 189193. doi:10.1080/18811248.1999.9726197

[4] F. Spedding and A. Dahan, "Rare Earth Metals," Metallurgy, Moscow, 1965.

[5] H. Yosisuke, "Metal Technologies (Tokyo)," 1988.

[6] J. A. Plambeck, "Encyclopedia of Electrochemistry of the Elements," Volume X Fused Salt Systems, Marcel Dek- ker, New York, 1976.

[7] C. V. Banks, M. R. Heusinkveld and J. W. O'Laughlin, "Absorption Spectra of the Lanthanides in Fused Lithium Chloride-Potassium Chloride Eutectic," Analytical Chemistry, Vol. 33, No. 9, 1961, pp. 1235-1240. doi:10.1021/ac60177a032

[8] K. E. Johnson and J. R. Mackenzie, "Samarium, Europium and Ytterbium Electrode Potentials in LiCl-KCl Eutectic melt," Journal of the Electrochemical Society, Vol. 116, No. 12, 1969, pp. 1697-1703. doi:10.1149/1.2411665

[9] T. Ogawa and K. Minato, "Dissolution and Formation of Nuclear Materials in Molten Media," Pure Applied Chemistry, Vol. 73, No. 5, 2001, p. 799. doi:10.1351/pac200173050799

[10] K. Franklin, F. Kobayashi, M. Akabori, M. Takano, A. Itoh and T. Ogawa, "A Study on the Electrode Potential of Dysprosium Metal and Dysprosium Nitride in LiCl$\mathrm{KCl}$ Eutectic Salt," Paper Presented at the 31st Symposium on Molten Salt Chemistry, Sendai, 1999.

[11] J. Sheng, H. Yamana and H. Moriyama, "Activity Coefficients of Dy Dissolved in Liquid Bi," Journal of Nuclear Materials, Vol. 301, No. 2-3, 2002, p. 220. doi:10.1016/S0022-3115(02)00702-X

[12] K. G. Chang, X. P. Ping Lu, Y. Y. Du and M. S. Zhao, "Determination of the Apparent Standard Potential of the Dy/Dy(III) System in the LiCl-KCl Eutectic," Chinical Journal of Chemistry, Vol. 12, No. 6, 1994, p. 509. doi:10.1002/cjoc. 19940120605

[13] I. Masatoshi, "Diffusion Coefficient of Cerium and Gadolinium in Molten LiCl-KCl," Journal of the Electrochemical Society, Vol. 145, No. 1, 1998, pp. 84-88. doi:10.1149/1.1838216

[14] F. Lantelme and Y. Berghoute, "Electrochemical Studies of $\mathrm{LaCl}_{3}$ and $\mathrm{GdCl}_{3}$ Dissolved in Fused LiCl-KCl," Journal of the Electrochemical Society, Vol. 146, No. 11, 1999, pp. 4137-4144. doi:10.1149/1.1392604

[15] M. R. Beimejo, J. Gomez, J. Medina, A. M. Martinez and Y. Castrillejo, "The Electrochemistry of Gadolinium in the Eutectic LiCl-KCl on W and Al Electrodes," Journal of Electroanalytical Chemistry, Vol. 588, No. 2, 2006, pp. 253-266. doi:10.1016/j.jelechem.2005.12.031

[16] C. Caravaca, G. de Cordoba, M. J. Tomas and M. Rosado, "Electrochemical Behavior of Gadolinium Ion in Molten LiCl-KCl Eutectic," Journal of Nuclear Materials, Vol. 360 , No. 1, 2007, pp. 25-31. doi:10.1016/j.jnucmat.2006.08.009

[17] Y. Castrillejo', M. R. Bermejo, A. M. Martinez, E. Barrado and P. Diaz Arocas, "Application of Electrochemical Techniques in Pirochemical Processes-Electrochemical Behavior of Rare Earth at W, Cd, Bi and Al Electrodes," Journal of Nuclear Materials, Vol. 360, No. 1, 2007, pp. 32-42. doi:10.1016/j.jnucmat.2006.08.011

[18] Y. Castrillejoa', M. R. Bermejoa, A. I. Barradoa, R. Pardoa, E. Barradoa and A. M. Martlnez, "Electrochemical Behavior of Dy in LiCl-KCl Eutectic Melt on W and $\mathrm{Al}$ Electrodes," Electrochimica Acta, Vol. 50, No. 10, 2005. pp. 2047-2057.

[19] H. B. Kushkhov, A. S. Uzdenova, M. K. Vindizheva and 
A. V. Zimin, "Investigation of Electroreduction of Gadolinium and Samarium Ions in Halide Melts," Ukr. Chemical Journal, Vol. 66, No. 7, 2000, pp. 50-54.

[20] H. B. Kushkhov and A. S. Uzdenova, "Electrochemical Behavior of Gadolinium Ion in Halide Melts," Vestnik KBSU, Chemical Sciences, Nalchik, Vol. 2, 1997, pp. 1316.

[21] H. B. Kushkhov and A. S. Uzdenova, "Mechanism of Gadolinium Ion Electroreduction in Halide Melts," Proceedings of the XI Conference on Physical Chemistry and Electrochemistry of Molten and Solid Electrolytes, Ekaterinburg, Vol. 1, 1998, pp. 245-246.

[22] H. B. Kushkhov, M. K. Vindizheva, R. A. Mukozheva, M. R. Tlenkopachev and M. N. Nafonova, "Investigation of Lanthanum Ions Electroreduction on Tungsten Electrode in Halide Melts at $823 \mathrm{~K}$," Melts, No. 1, 2012, pp. 1-10.

[23] H. B. Kushkhov, A. S. Uzdenova and D. L. Shogenova, "Electroreduction of Yttrium Ions on Silver and Tungsten Electrodes in Chloride and Chloride-Fluoride Melts at 823K," Melts, No. 2, 2006, pp. 55-64.

[24] H. B. Kushkhov, Z. A. Zhanikaeva and S. I. Chuksin, "Electroreduction of Neodymium Ions in Chloride Melts,"
Melts, No. 3, 2009, pp. 50-59.

[25] G. Brouwer, et al., "A Guide to Inorganic Synthesis," M.: Mir, Vol. 4, 1985, 447 p.

[26] S. A. Kuznetsov and M. Gaune-Escard, "Redox Electrochemistry and Formal Standard Redox Potentials of the $\mathrm{Eu}(\mathrm{III}) / \mathrm{Eu}$ (II) Redox Couple in an Equimolar Mixture of Molten NaCl-KCl," Electrochimica Acta, Vol. 46, No. 8, 2001, pp. 1101-1111. doi:10.1016/S0013-4686(00)00708-8

[27] S. Y. Griliches, "Electrochemical and Chemical Polishing," L.: Mashinostroenie, 1987, pp. 107-128.

[28] Y. Heyrovský and Y. Kuta, "Basics Polarography," M.: Mir, 1965, $559 \mathrm{p}$.

[29] F. Stolz, "Electroanalytical Methods. Theory and Practice," Publishing House, Beanom, Knowledge Laboratory, 2010, $326 \mathrm{p}$.

[30] E. Jaeger and F. Zalkind, "Methods of Electrochemistry Measurements," M.: Mir, 1977, 585 p.

[31] P. Delahey, "New Apparatus and Methods in Electrochemistry," 1957. 